\title{
Metabolic effects on growth and muscle of soya-bean protein feeding in cod (Gadus morhua)
}

\author{
BYA. VON DER DECKEN \\ The Wenner-Gren Institute for Experimental Biology, University of Stockholm, S-106 91 Stockholm, \\ Sweden \\ AND E. LIED \\ Nutrition Institute, Directorate of Fisheries, $N-5024$ Bergen, Norway
}

(Received 13 March 1992 - Accepted 4 June 1992)

\begin{abstract}
The aim of the present study was to investigate the effect of soya-bean protein on growth and muscle metabolism in fish. Cod, Gadus morhua, were fed on a fish-feed formula with the high-quality fish-meal protein being replaced by 100,200 or $300 \mathrm{~g}$ soya-bean protein $/ \mathrm{kg}$ fish-meal protein. The feeding experiment lasted for $43 \mathrm{~d}$ at a water temperature of $7-8^{\circ}$ and a sea water salinity of $3.5 \%$. At the $200 \mathrm{~g} / \mathrm{kg}$ level of soya-bean protein, food intake and growth rate were similar to those of the controls. At the $300 \mathrm{~g} / \mathrm{kg}$ level of soya-bean protein, food intake was diminished by $6 \%$ and growth by $67 \%$ relative to control levels. In muscle, sarcoplasmic protein (/g wet weight) was significantly decreased by $14 \%$. Myofibrillar protein (/g wet weight) was unchanged. Levels of RNA in the myofibrillar fraction decreased at all three levels of soya-bean protein, and that of the sarcoplasmic fraction decreased at the highest level of legume-protein. With increased levels of soya-bean protein, RNA:DNA declined by $18 \%$ from 1.88 to 1.54 . The contractile protein myosin heavy chain (/mg protein and /g wet weight) and myosin heavy chain-specific mRNA (/mg RNA) were not significantly affected by dietary conditions. Expressed per $\mathrm{g}$ wet weight, the decline by $21 \%$ of the specific mRNA depended on the total RNA content which decreased with the increase in soya-bean protein. Acid proteinase activity was lowest at the $200 \mathrm{~g} / \mathrm{kg}$ level, showing a decrease of $23 \%$. Glycogen content fell by $46 \%$ at both the 200 and $300 \mathrm{~g} / \mathrm{kg}$ level of dietary soya-bean protein. The results show that muscle metabolic functions responded to the dietary plant protein before there were any measurable changes in growth rate. From the results it is concluded that $200 \mathrm{~g} / \mathrm{kg}$ or less of the high-quality fish-meal protein may be replaced by soya-bean protein in a fish-feed formula.
\end{abstract}

Soya-bean protein: Muscle metabolism: Fish

For reasons of world animal protection and also of economy it has been proposed to replace, where possible, food sources of animal origin by those of vegetable origin. Fish require a high amount of protein in their diets. The feed for carnivores such as cod (Gadus morhua) contains $30-50 \%$ of the total food energy in the form of proteins (Lied \& Rosenlund, 1984). High-quality fish-meals supply the major portion of the protein in commercial rations formulated for cold-water fish in intense culture systems (Tacon \& Jackson, 1985). Soya beans are among the protein sources that have been considered to replace the fish-meal component. In farm-animal feeds soya beans have been widely used as a protein source (Circle \& Smith, 1972). The plant protein contains heat-sensitive trypsin inhibitors which along with other inhibitors are inactivated by extrusion (Tacon \& Jackson, 1985). In isolated soya-bean proteins methionine is the first limiting amino acid. The concentration is significantly less than that found in casein and will, therefore, affect growth 
(Block \& Bolling, 1947). Isolated soya-bean proteins have a high availability of lysine (Batterham et al. 1990).

The present experiments were designed to replace part of the animal protein source in a fish-feed formula by soya beans. A moderate content of the legume protein was found to be acceptable to the fish. Too high an amount diminished the growth rate and changed muscle metabolic variables.

\section{MATERIALS AND METHODS}

\section{Materials}

All chemicals of the highest purity available were supplied by Sigma Chemical Co. (St Louis, MO, USA) and Serva (Heidelberg, Germany). Additional chemicals have been listed previously (von der Decken \& Lied, 1992).

\section{Fish and diets}

Cod, averaging $40 \mathrm{~g}$, were obtained from Parispollen (Oygarden, Norway). The feeding experiment was carried out in sheltered $300 \mathrm{l}$ aquaria supplied with sea water running at $4-51 / \mathrm{min}$, a constant temperature of $7-8^{\circ}$ and $3.5 \%$ salinity. The photoperiod was automatically regulated to $12 \mathrm{~h}$ light $-12 \mathrm{~h}$ dark. The fish were acclimated for 4 weeks to the experimental conditions and daily were fed ad lib. the diet of feeding group 0 (Table 2). The feeding experiment was carried out with eight groups (two groups for each of the four treatments; treatment groups $0,10,20$ and 30), each containing fifteen fish. The duplicate groups were fed once daily. Food was withdrawn when all fish were satiated. The basic composition of the dietary ingredients is given in Table 1. The different diets (Table 2) contained increasing amounts of protein energy derived from full-fat soya beans, replacing the protein energy derived from fish muscle.

The energy distribution ( $\%$ ) within each diet was as follows; protein energy 60 , fat energy 25 , carbohydrate energy 15 . Protein $(\mathrm{N} \times 6.25)$ content was determined by a modified Kjeldahl procedure (Crooke \& Simpson, 1971), lipids gravimetrically using the ethyl acetate extract, ash gravimetrically after ashing for $24 \mathrm{~h}$ at $660^{\circ}$, dry matter gravimetrically after drying for $24 \mathrm{~h}$ at $105^{\circ}$ and water as the weight difference after drying. Carbohydrate was estimated as the difference in weight between the sum of the analytical values described previously and the original weight of the food.

At the end of the feeding experiment, $43 \mathrm{~d}$, the fish were starved for $3 \mathrm{~d}$ and then killed by a blow to the head and weighed. The white type muscle of the epaxial muscle was dissected, and slices of the muscle were wrapped in aluminium foil, immediately frozen between two solid blocks of $\mathrm{CO}_{2}$ and stored at $-80^{\circ}$ (Lund \& von der Decken, 1980).

\section{Sarcoplasmic and myofibrillar fraction of skeletal muscle}

Muscle $(500 \mathrm{mg})$ was thawed and homogenized in $10 \mathrm{~mm}$-sodium phosphate buffer, $0 \cdot 125 \mathrm{M}-\mathrm{NaCl}, 0 \cdot 1 \mathrm{~mm}$-EDTA, pH 7 and the homogenate centrifuged at $5000 \mathrm{~g}$ for $20 \mathrm{~min}$. The $5000 \mathrm{~g}$ supernatant fraction was enriched with sarcoplasmic proteins and the pellet fraction with myofibrillar proteins (Nazar et al. 1991). Portions of the total homogenate were analysed for DNA, RNA and protein, and the sarcoplasmic and myofibrillar fractions for RNA and protein (see p. 692).

\section{Immunoassay}

An enzyme-linked immunosorbent assay (ELISA) was used to determine the content of myosin heavy chain in the total homogenate (Persson et al. 1991). Muscle (250 mg) was homogenized in $10 \mathrm{mM}$-sodium phosphate buffer, $0 \cdot 125 \mathrm{M}-\mathrm{KCl}, 0 \cdot 1 \mathrm{mM}$-EDTA and glycerol $(500 \mathrm{ml} / 1)$. The homogenate was diluted 12 -fold with $10 \mathrm{~mm}$-sodium phosphate buffer and 
Table. 1. Basic composition of the dietary ingredients $(\mathrm{g} / \mathrm{kg})$

\begin{tabular}{|c|c|c|c|c|}
\hline Ingredients & Protein & Fat & Carbohydrate & Ash \\
\hline $\begin{array}{l}\text { Squid (Gonatis } \\
\text { fabricii) mantle* }\end{array}$ & 200 & 0 & 0 & 10 \\
\hline $\begin{array}{l}\text { Fish-meal of cod } \dagger \\
\text { (Gadus morhua) }\end{array}$ & 910 & 25 & 0 & 0 \\
\hline $\begin{array}{l}\text { Capelin (Mallotus } \\
\text { vilosus) oil } \$\end{array}$ & 0 & 1000 & 0 & 0 \\
\hline Maize dextrin§ & 0 & 0 & 1000 & 0 \\
\hline $\begin{array}{l}\text { Full-fat soya } \\
\text { bean } \|\end{array}$ & 380 & 195 & 220 & 45 \\
\hline Salmomix BT & 110 & 80 & 630 & 35 \\
\hline
\end{tabular}

* Leröy, Bergen, Norway.

$\dagger$ Toro, Bergen, Norway.

$\ddagger$ Norsild Mel, Bergen, Norway.

$\S$ Commercially available.

II Instapro Europe, Cheltenham, UK; the full-fat soya bean was extruded for $3 \mathrm{~s}$ at $120^{\circ}$.

I Skretting, Stavanger, Norway.

Table. 2. Composition of the diets $(\mathrm{g} / \mathrm{kg})$ fed to cod (Gadus morhua) of which group $(0)$ was fed on fish-meal protein and for groups 10, 20 and 30 the fish-meal protein was replaced with 100,200 or $300 \mathrm{~g}$ soya-bean protein $/ \mathrm{kg}$ respectively; the corresponding content of the vegetable soya-bean fat being 0 (group 0), 280,570 and $860 \mathrm{~g} / \mathrm{kg}$ for groups 10, 20 and 30 respectively*

\begin{tabular}{|c|c|c|c|c|}
\hline \multirow[b]{2}{*}{ lngredients } & \multicolumn{4}{|c|}{ Feeding group } \\
\hline & 0 & 10 & 20 & 30 \\
\hline $\begin{array}{l}\text { Squid (Gonatis } \\
\text { fabricii) mantle }\end{array}$ & 300 & 300 & 300 & 300 \\
\hline $\begin{array}{l}\text { Fish meal of cod } \\
\text { (Gadus morhua }) \ddagger\end{array}$ & 256 & 222 & 190 & 157 \\
\hline $\begin{array}{l}\text { Capelin (Mallotus } \\
\text { vilosus) oilई }\end{array}$ & 51 & 37 & 22 & 7 \\
\hline Maize dextrin $\|$ & 60 & 43 & 25 & 8 \\
\hline $\begin{array}{l}\text { Full-fat soya } \\
\text { bean }\end{array}$ & 0 & 79 & 158 & 237 \\
\hline Salmomix B** & 68 & 68 & 68 & 68 \\
\hline Water & 270 & 256 & 242 & 228 \\
\hline
\end{tabular}

* The energy content was $8.36 \mathrm{MJ} / \mathrm{kg}(2000 \mathrm{kcal} / \mathrm{kg})$ diet.

$\dagger$ Leröy, Bergen, Norway.

+ Toro, Bergen, Norway.

$\S$ Norsild Mel, Bergen, Norway.

$\|$ Commercially available.

Instapro Europe, Cheltenham, UK; the full-fat soya bean was extruded for $3 \mathrm{~s}$ at $120^{\circ}$.

** Skretting, Stavanger, Norway.

$0.45 \mathrm{M}-\mathrm{KCl}, \mathrm{pH} 7$, before pipetting into the wells of the microtitre plates coated with purified myosin heavy chain of cod. As primary antibodies, those against myosin heavy chain from cod were added (Lied \& von der Decken, 1985). As secondary antibodies, antirabbit IgG antibodies conjugated with alkaline phosphatase (EC 3.1.3.1) were used. To develop the colour, $p$-nitrophenyl phosphate was added. Purified myosin heavy chain from cod was used as standard. 
Table. 3. Body weight gain and specific growth rate (SGR) of cod (Gadus morhua) fed on fish-meal protein (0) or fish-meal protein replaced by $100(10)$, or $200(20)$ or $300(30) \mathrm{g}$ soya-bean protein $/ \mathrm{kg} \dagger$

(Mean values with their standard errors for fifteen fish per group)

\begin{tabular}{|c|c|c|c|c|c|c|c|c|}
\hline & \multicolumn{8}{|c|}{ Feeding group } \\
\hline & \multicolumn{2}{|c|}{0} & \multicolumn{2}{|c|}{10} & \multicolumn{2}{|l|}{20} & \multicolumn{2}{|c|}{30} \\
\hline & Mean & $\mathrm{SE}$ & Mean & $\mathrm{SE}$ & Mean & $\mathrm{SE}$ & Mean & SE \\
\hline Final body wt & $79 \cdot 0^{\mathrm{a}}$ & 3.0 & $77 \cdot 3^{a}$ & $2 \cdot 7$ & $77 \cdot 3^{\mathrm{a}, \mathrm{b}}$ & $5 \cdot 5$ & $65 \cdot 3^{\mathrm{b} *}$ & 3.9 \\
\hline $\operatorname{SGR}(\% / \mathrm{d}) \neq$ & 0.70 & & 0.65 & & 0.65 & & 0.26 & \\
\hline $\mathrm{Wt}$ gain $(\%)$ & $35 \cdot 4$ & & $32 \cdot 4$ & & $32 \cdot 3$ & & $11 \cdot 8$ & \\
\hline $\begin{array}{l}\text { Food intake } \\
\text { (g dry matter } / \mathrm{kg} \\
\text { body wt per } \mathrm{d} \text { ) }\end{array}$ & $5 \cdot 1$ & & $5 \cdot 2$ & & $5 \cdot 1$ & & $4 \cdot 8$ & \\
\hline
\end{tabular}

\footnotetext{
a, b Values with different superscript letters were significantly different $(\mathrm{P}<0.05)$. Difference between groups 20 and 30 was marginally significant : ${ }^{*} P=0.086$.

$\dagger$ For details of diets and procedures, see Tables 1 and 2 and pp. 690-692.

$\ddagger \frac{\ln \text { final body weight }-\ln \text { initial body weight }}{\text { feeding days (43) }} \times 100$.
}

\section{$c D N A-m R N A$ hybridization}

The level of the myosin specific mRNA was measured by dot hybridization. The details are given elsewhere (von der Decken \& Lied, 1992). QuickHyb ${ }^{\mathrm{TM}}$ Rapid Hybridization Solution (Stratagene, La Jolla, CA, USA) was used.

\section{Analyses}

DNA was estimated by the fluorescent method using salmon DNA as a standard (Setaro \& Morley, 1976). Proteins were determined by the Coomassie brilliant blue method (Bradford, 1976). RNA was determined after alkaline digestion of the perchloric acid precipitate (Fleck \& Munro, 1962). Glycogen was determined as described by Harris et al. (1974). The glycogen content was expressed as $\mathrm{mg}$ glucose/g wet weight of tissue. Acid proteinase was determined in the supernatant fraction obtained after centrifugation of the total homogenate for $10 \mathrm{~min}$ at $1600 \mathrm{~g}$ (Mommsen et al. 1980); haemoglobin was used as the substrate and the tyrosine released was measured by a fluorescent method (Ambrose, 1974). The values were expressed as $\mathrm{mg}$ tyrosine released from haemoglobin $/ \mathrm{h}$.

\section{Statistical analysis}

The results are expressed as means with their standard errors. Data were analysed using one-way analysis of variance and Newman-Keul's test for multiple-sample comparison or by regression analysis (Snedecor \& Cochran, 1980).

\section{RESULTS}

Food intake, body and muscle weights

Food intake was similar among the groups 0, 10 and 20 (Table 3). Food intake level of group 30 was lower than that of the other groups. Final body weights were similar for groups 0,10 and 20 and significantly diminished for group 30 (Table 3). Specific growth 


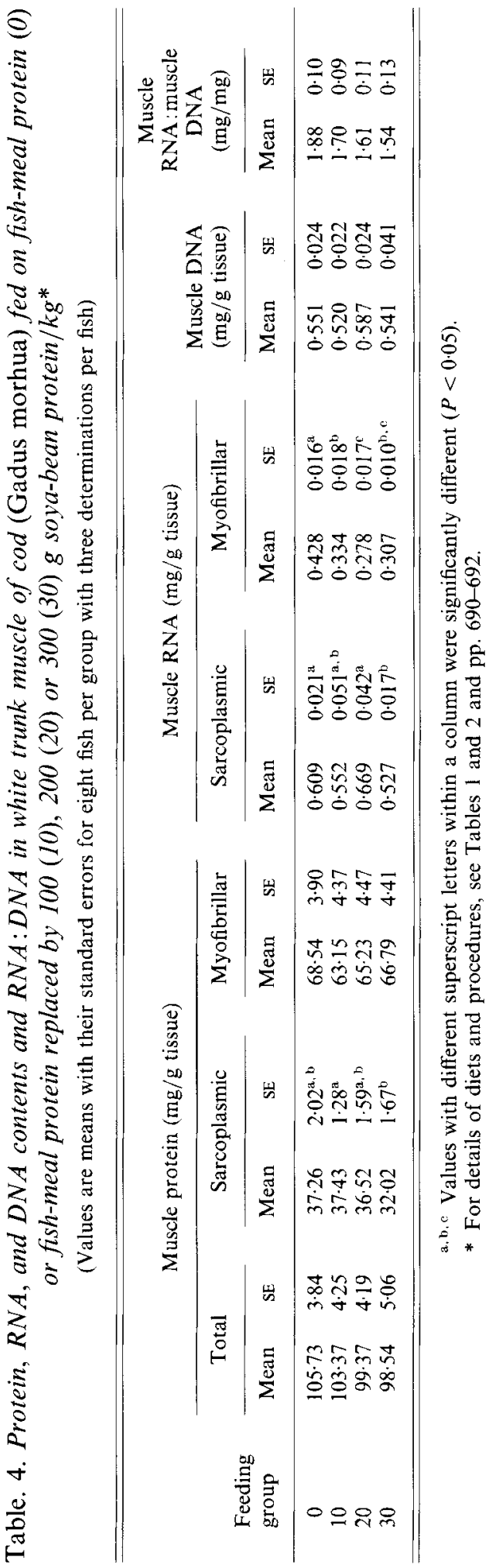


Table. 5. Content of myosin heavy chain in white trunk muscle of cod (Gadus morhua) fed on fish-meal protein (0) or fish-meal protein replaced by $100(10), 200(20)$ or $300(30)$ $\mathrm{g}$ soya-bean protein $/ \mathrm{kg}^{*}$

(Values are means with their standard errors for four fish per group)

\begin{tabular}{|c|c|c|c|c|}
\hline \multirow{3}{*}{$\begin{array}{l}\text { Feeding } \\
\text { group }\end{array}$} & \multicolumn{4}{|c|}{ Myosin heavy chain } \\
\hline & \multicolumn{2}{|c|}{$\mathrm{mg} / \mathrm{mg}$ protein } & \multicolumn{2}{|c|}{$\mathrm{mg} / \mathrm{g}$ tissue } \\
\hline & Mean & SE & Mean & $\mathrm{SE}$ \\
\hline 0 & $0 \cdot 220$ & 0.012 & $23 \cdot 29$ & $2 \cdot 12$ \\
\hline 10 & 0.235 & 0.017 & $24 \cdot 33$ & $2 \cdot 76$ \\
\hline 20 & $0 \cdot 252$ & $0 \cdot 014$ & $25 \cdot 04$ & $2 \cdot 42$ \\
\hline 30 & $0 \cdot 247$ & $0 \cdot 010$ & $24 \cdot 32$ & 2.22 \\
\hline
\end{tabular}

* For details of diets and procedures, see Tables 1 and 2 and pp. 690-691.

Table. 6. Hybridization of RNA with $c D N A$ specific for myosin heavy chain in white trunk muscle of cod (Gadus morhua) fed on fish-meal protein (0) or fish-meal protein replaced by $100(10), 200(20)$ or $300(30) \mathrm{g}$ soya-bean protein $/ \mathrm{kg}^{*}$

(Mean values with their standard errors for six fish per group)

\begin{tabular}{|c|c|c|c|c|}
\hline \multirow{2}{*}{$\begin{array}{l}\text { Feeding } \\
\text { group }\end{array}$} & \multicolumn{2}{|c|}{$\mathrm{Dpm} / \mu \mathrm{g}$ RNA } & \multicolumn{2}{|c|}{$\mathrm{Dpm} / \mathrm{g}$ wet wt } \\
\hline & Mean & $\mathrm{SE}$ & Mean & $\mathrm{SE}$ \\
\hline 0 & 440 & 18 & $455 \times 10^{3}$ & $24 \times 10^{3}$ \\
\hline 10 & 495 & 33 & $440 \times 10^{3}$ & $42 \times 10^{3}$ \\
\hline 20 & 420 & 12 & $395 \times 10^{3}$ & $27 \times 10^{3}$ \\
\hline 30 & 435 & 12 & $360 \times 10^{3}$ & $15 \times 10^{3}$ \\
\hline
\end{tabular}

$\mathrm{dpm}$, disintegrations/min.

* For details of diets and procedures, see Table 1 and 2 and pp. 690 and 692.

rate (SGR) expressed as $\% / \mathrm{d}$ and percentage weight gain were also lowest in group 30 . Muscle wet weight was 53.4 (SE 1.2) \% of body wet weight. The percentage value was the same for the four feeding groups. Muscle represented $21 \cdot 3 \%$ of body dry weight. On a dry weight basis muscle consisted of $(\mathrm{g} / \mathrm{kg})$ protein 836 , fat 100 , ash 59 .

\section{Content of protein, RNA and DNA in epaxial muscle}

Protein content ( $\mathrm{g}$ wet weight of epaxial muscle) was not significantly changed by the diets (Table 4). The trend towards a decrease in muscle protein with increasing amounts of soyabean protein became clear when the protein content of the sarcoplasmic fraction was determined separately (Table 4). A significant difference was reached between groups 10 and 30. Myofibrillar proteins seemed less affected by the dietary conditions. The RNA content of the myofibrillar fraction was significantly decreased with increasing soya bean in the diet (Table 4). The changes in RNA of the sarcoplasmic fraction were less marked, but there was a significant decrease in group 30 . The DNA concentration (/g wet weight of tissue) showed dietary treatment had little effect. RNA:DNA values declined with increasing dietary soya-bean protein, although differences between the groups were not 


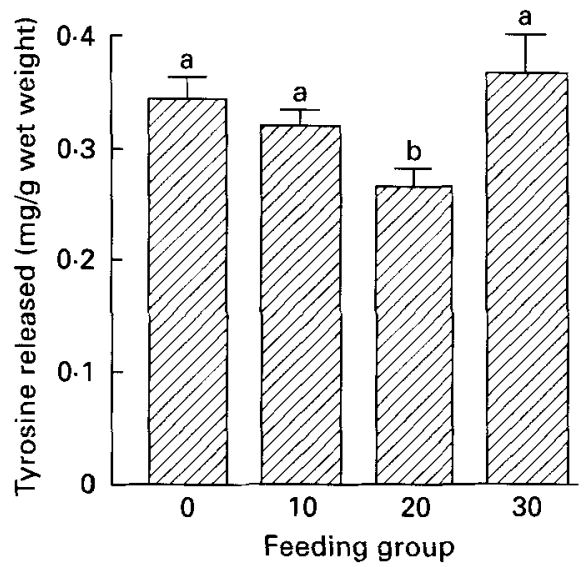

Fig. 1. Effect of feeding fish-meal protein (0), fish-meal protein replaced by $100(10), 200(20)$ and 300 (30) $\mathrm{g}$ soyabean protein $/ \mathrm{kg}$ protein on acid proteinase activity (/g wet weight of muscle) of cod (Gadus morhua). Values are means with their standard errors, represented by vertical bars, for eight fish. Means with different superscript letters were significantly different from each other $(P<0.05)$. For details of diets and procedures, see Tables 1 and 2 and pp. 690 and 692.

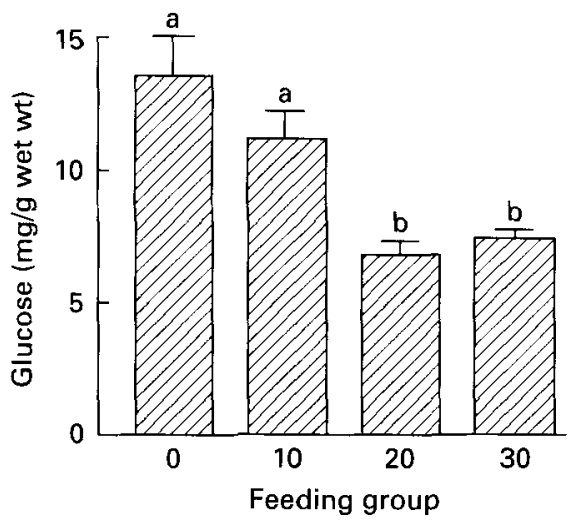

Fig. 2. Effect of feeding fish-meal protein (0), fish-meal protein replaced by $100(10), 200(20)$ and $300(30) \mathrm{g}$ soyabean $/ \mathrm{kg}$ protein on glycogen content $(\mathrm{mg}$ glucose $/ \mathrm{g}$ wet weight of muscle) of cod (Gadus morhua). Values are means with their standard errors, represented by vertical bars, for eight fish. Means with different superscript letters were significantly different from each other $(P<0.05)$. For details of diets and procedures, see Tables 1 and 2 and pp. 690 and 692.

significant. Regression analysis of RNA:DNA $v$. diet gave a slope value of -0.011 (SE 0.0018 ) which was significantly different from zero, $P=0.025$.

\section{Myosin heavy chain}

One of the contractile proteins, myosin heavy chain, was estimated by the ELISA technique (Table 5). No diet-dependent changes were noted in levels expressed on a per $g$ wet weight of muscle basis. With the content of myofibrillar proteins being constant a slight but not significant rise was seen when expressed on a per mg total protein basis (Table 5). The amount of myosin heavy chain-specific mRNA (/mg total RNA) showed no significant differences between the groups (Table 6). On a per $g$ wet weight basis, there was a decrease with increasing dietary soya-bean protein. Regression analysis of radioactivity 
(disintegrations/min per g wet weight) $v$. diet gave a slope value of $-3.3 \times 10^{3}$ (SE $0.4 \times 10^{3}$ ) which was significantly different from zero, $P=0 \cdot 016$.

\section{Acid proteinase activity and glycogen content in muscle}

Acid proteinase activity (/g wet weight of muscle) was significantly lowest in group 20 (Fig. 1). Activity increased again as the dietary soya-bean protein content increased to $300 \mathrm{~g} / \mathrm{kg}$ fish-meal protein. Glycogen content (/g wet weight of muscle) was highest in the feeding group 0 and decreased significantly in groups 20 and 30 (Fig. 2).

\section{DISCUSSION}

The replacement of $200 \mathrm{~g} / \mathrm{kg}$ high-quality fish-meal protein by soya-bean protein (group 20) allowed for normal growth of the fish. At a replacement level of $300 \mathrm{~g} / \mathrm{kg}$, growth rate declined. There are no plant feed proteins available with an amino acid profile approximating to that of dietary requirements of farmed fish (Tacon \& Jackson, 1985), and total replacement of fish meal by plant proteins has met with little success. Complementing the feed formulas with other protein sources or single amino acids has been employed (Ketola, 1982).

The reduced food intake associated with high levels of plant proteins might be caused by the shortage of one essential amino acid, in this case methionine, triggering a metabolic mechanism of food intake regulation. Shortage of a single amino acid causes excess of the other body amino acids to be deaminated in the liver. The $\mathrm{C}$ skeleton is utilized in hepatic carbohydrate intermediary metabolism (Cowey \& Walton, 1989). A different causative factor for reduced food intake may be feed palatability which is lower when large amounts of plant proteins are fed (Mackie \& Mitchell, 1985).

The turnover of proteins depends on the rates of synthesis and degradation. The decrease in sarcoplasmic proteins together with a diminished acid proteinase activity, as seen in group 20, suggested a low protein synthetic activity. In group 30 acid proteinase activity was restored and the sarcoplasmic protein content remained low, indicating that protein synthetic activity was insufficient to overcome protein degradation. Sarcoplasmic proteins were affected more by the dietary conditions than those of the contractile elements. In salmon, during spawning migration, sarcoplasmic proteins are degraded before the contractile components by acid proteinases (Ando et al. 1986).

A low-protein synthetic activity was confirmed by the RNA concentration (/g wet weight of muscle). It decreased with the rise in dietary soya-bean protein, the changes being more noticeable in the myofibrillar fraction than in the sarcoplasmic fraction. The content of mRNA specific for the contractile protein myosin heavy chain followed the pattern of a decrease in total RNA and appeared to be closely related to it. The major part of cellular RNA is of ribosomal origin and is used as a measure of the capacity for protein synthesis (Omstedt \& von der Decken, 1972).

With the increase in soya-bean protein the deposition of glycogen in muscle fell. The substrate for muscle glycogen synthesis is glucose. In fish muscle, deaminated amino acids are utilized only to a limited extent in the gluconeogenic pathway (Suarez \& Mommsen, 1987).

When $300 \mathrm{~g} / \mathrm{kg}$ fish-meal was replaced by soya-bean protein the changes in muscle metabolism were confirmed by a decline in growth rate. Muscle metabolic changes in acid proteinase activity, glycogen and myofibrillar RNA content and myosin heavy chainmRNA levels were noticeable at 100 and $200 \mathrm{~g}$ legume protein $/ \mathrm{kg}$. Muscle metabolic functions responded to the dietary plant proteins before measurable changes in growth rate. From the above results it is concluded that $200 \mathrm{~g} / \mathrm{kg}$ or less of the high-quality fishmeal protein may be replaced by soya-bean protein in a fish-feed formula. 
The work was supported by a grant to A.v.d. D. from the Swedish Council for Forestry and Agricultural Research (Project no. 851/89 V 82:3) and a joint grant from the Nordiska Ministerrådet (Project no. 66991.21.015/90). The competent technical assistance of Ms S. Sundberg is gratefully acknowledged.

\section{REFERENCES}

Ambrose, J. A. (1974). Fluorometric measurement of tyrosine in serum and plasma. Clinical Chemistry 20 , 505-510.

Ando, S., Hatano, M. \& Zama, K. (1986). Protein degradation and protease activity of chum salmon (Oncorhynchus keta) muscle during spawning migration. Fish Physiology and Biochemistry 1, 17-26.

Batterham, E. S., Andersen, L. M., Baigent, D. R., Darnell, R. E. \& Taverner, M. R. (1990). A comparison of the availability and ileal digestibility of lysine in cottonseed and soya-bean meals for grower/finisher pigs. British Journal of Nutrition 64, 663-667.

Block, R. J. \& Bolling, D. (1947). The Amino Acid Composition Proteins and Foods, pp. 303-305. Springfield, IL: Charles Thomas.

Bradford, M. M. (1976). A rapid and sensitive method for the quantitation of microgram quantities of protein utilizing the principle of protein+dye binding. Analytical Biochemistry 72, 248-254.

Circle, S. J. \& Smith, A. K. (1972). Soybeans: Chemistry and Technology, pp. 264-338. Westport, CT: Avi Publishing.

Cowey, C. B. \& Walton, M. J. (1989). Intermediary metabolism. In Fish Nutrition, 2nd ed., pp. $259-329$ [J. E. Halver, editor]. New York and London: Academic Press.

Crooke, W. M. \& Simpson, W. E. (1971). Determination of ammonium in Kjeldahl digest of crops by an automated procedure. Journal of the Science of Food and Agriculture 22, 9-10.

Fleck, A. \& Munro, H. N. (1962). The precision of ultraviolet absorption measurements in the Schmidt-Thannhauser procedure for nucleic acid estimation. Biochimica et Biophysica Acta 55, 571-583.

Harris, R. C., Hultman, C. \& Nordesjö, L.-O. (1974). Glycogen, glycolytic intermediates and high-energy phosphates determined by biopsy samples of musculus Quadriceps femoris of men at rest. Methods and variance of values. Scandinavian Journal of Clinical and Laboratory Investigation 33, 109-120.

Ketola, H. G. (1982). Amino acid nutrition of fishes: requirements and supplementation of diets. Comparative Biochemistry and Physiology 73B, 17-24.

Lied, E. \& Rosenlund, G. (1984). The influence of the ratio of protein energy to total energy in the feed on the activity of protein synthesis in vitro, the level of ribosomal RNA and the RNA-DNA ratio in white trunk muscle of Atlantic cod (Gadus morhua). Comparative Biochemistry and Physiology 77A, 489-494.

Lied, E. \& von der Decken, A. (1985). Purification of fish muscle myosin heavy chain and quantification of the specific polyribosome-bound polypeptide. Biochemical Journal 232, 467-470.

Lund, B. \& von der Decken, A. (1980). Protein synthesis in vitro after cryopreservation of rat skeletal muscle. Zeitschrift für Tierphysiologie, Tierernährung und Futtermittelkunde 44, 255-266.

Mackie, A. M. \& Mitchell, A. I. (1985). Identification of gustatory feeding stimulants for fish - applications in aquaculture. In Nutrition and Feeding in Fish, pp. 177-189 [C. B. Cowey, A. M. Mackie and J. G. Bell, editors]. New York and London: Academic Press.

Mommsen, T. P., French, C. J. \& Hochachka, P. W. (1980). Sites and patterns of protein and amino acid utilization during the spawning migration of salmon. Canadian Journal of Zoology 58, 1785-1799.

Nazar, S. D., Persson, G., Olin, T., Waters, S. \& von der Decken, A. (1991). Sarcoplasmic and myofibrillar proteins in white trunk muscle of salmon (Salmo salar) after estradiol treatment. Comparative Biochemistry and Physiology 98B, 109-114.

Omstedt, P. T. \& von der Decken, A. (1972). The influence of the nutritive value of proteins on the level of protein synthesis in vitro in rat skeletal muscle. British Journal of Nutrition 27, 467-474.

Persson, G., Löfberg, E. H. A. \& von der Decken, A. (1991). Antigenicity of myosin heavy chain from skeletal muscle of fish species and humans as determined by the ELISA technique. Biochemical Archives $7,1-11$.

Setaro, F. \& Morley, C. G. D. (1976). A modified fluorometric method for the determination of microgram quantities of DNA from cell or tissue cultures. Analytical, Biochemistry 71, 313-317.

Snedecor, G. W. \& Cochran, W. G. (1980). Statistical Methods, 7th ed., pp. 149-174, 235-237. Ames, IA: The lowa State University Press.

Suarez, R. K. \& Mommsen, T. P. (1987). Gluconeogenesis in teleost fishes. Canadian Journal of Zoology 65 , 1869-1882.

Tacon, A. G. J. \& Jackson, A. J. (1985). Utilisation of conventional and unconventional protein sources in practical fish feeds. In Nutrition and Feeding in Fish, pp. 119-145 [C. B. Cowey, A. M. Mackie and J. G. Bell, editors). New York and London: Academic Press.

von der Decken, A. \& Lied, E. (1992). Dietary protein levels affect growth and protein metabolism in trunk muscle of cod, Gadus morhua. Journal of Comparative Physiology B 162, 351-357. 